\title{
NO REVERSAL OF FORTUNE IN THE LONG RUN: GEOGRAPHY AND SPATIAL PERSISTENCE OF PROSPERITY IN COLOMBIA, 1500-2005*
}

ADOLFO MEISEL

Banco de la República ${ }^{\mathrm{a}}$

\begin{abstract}
This paper examines the non-reversal of fortune thesis proposed by Acemoglu et al. (2002) in the light of the Colombian experience over the last 500 years. Using a total of fourteen national population censuses and the record of tributary Indians in 1559, it is found that the population density of Colombian regions presented a high degree of persistence through time. Thus, the evidence indicates that those places that were prosperous circa 1500 remain so today, and vice versa. These results indicate that the long-run influences of geography on regional economic disparities within a country are not negligible.
\end{abstract}

Keywords: comparative economic history, demographic economics, Latin America

JEL Code: N16, J10, N36

* Received 23 January 2014. Accepted 8 October 2014. Paper presented at the 9th BETA Workshop in Historical Economics, New Data, Methods, and Theories in Cliometrics, Strasbourg, 3-4 May 2013. The research assistance of Simon Chaves and Yuri Reina and comments by the members of CEER, Banco de la República, Cartagena, Colombia, Felipe Valencia Caicedo, Maria Teresa Ramirez, Haroldo Calvo, Enrique Lopez, and Juliana Jaramillo, are acknowledged. The opinions expressed in this paper do not reflect the point of view of the Banco de la República or its Board of Directors.

a Carrera 7 \#14-78, Bogotá, Colombia. ameisero@banrep.gov.co 


\section{RESUMEN}

Este trabajo examina la tesis de la no reversión de la fortuna propuesta por Acemoglu, Johnson y Robinson en el contexto de la experiencia de Colombia durante los últimos 500 años. Utilizando un total de 14 censos nacionales y un recuento de los indígenas que pagaban impuestos en 1559, se demuestra que la densidad de población de las regiones colombianas ha sido muy persistente a través del tiempo. Por lo tanto, los sitios que eran prósperos en 1500 tienden a ser los mismos en la actualidad y viceversa. Estos resultados sugieren que el papel de la geografía en las disparidades regionales al interior de un país no es despreciable.

Palabras clave: historia económica comparada, demografía económica, América Latina

\section{INTRODUCTION}

Over the last two decades the work of Daron Acemoglu, Simon Johnson, and James A. Robinson and their associates has enriched the debate regarding the long-run determinants of economic prosperity. Their contributions in this field have been both theoretical and empirical.

Their main message on the matter is quite clear: in the long run, institutions are the predominant reason why some places grow rich, while others stagnate. One of the empirical arguments developed by Acemoglu, Johnson and Robinson to demonstrate the primacy of institutions over other possible determinants of long-run prosperity, such as geography, is what they have called the "reversal of fortune thesis». In their view, the European colonisation of the world, which began in the early $16^{\text {th }}$ century, dramatically changed the spatial distribution of wealth: those places that circa 1500 were the most prosperous became poor and remain so today and vice versa.

The reason for this reversal of fortunes is that in those places where there were large groups of indigenous inhabitants, the colonisers set up very extractive and exclusive institutions. Where the population density was low, the relative size of the colonizing group tended to be large and thus interested in establishing institutions favouring equality.

In this paper, I will show that for the case of the Colombian regions there was no reversal of fortune. Rather, what is observed is the continuity of relative prosperity. With few exceptions, those places which in 1500 were relatively rich remained prosperous throughout the centuries. This conclusion does not deny the enormous importance of institutions for long-run economic growth. However, it indicates that the role of geography cannot be discarded completely. Furthermore, from the persistence of relative prosperity through time at the sub-national level it cannot be inferred that reversal of fortune does 
not hold between countries. For example, if colonisers established a larger infrastructure and more complete state institutions in the regions of a country where more extractive institutions were set up, persistence could be observed over time as a result of path dependence. That this would occur, however, depended among other things on the type of productive activity involved. Alternatively, it is possible that there were some institutions that were similar throughout the territory of an administrative unit that later became a country and thus, the degree to which a reversal of fortune may occur could be much more limited at the sub-national level.

Colombia is an interesting case to study in relation to the long-run role of geography because it has one of the most rugged terrains in the tropics. The territory is divided south to north by three mountain ranges and, as a result, there are clearly differentiated geographic regions with very uneven levels of population densities and relative prosperity across the country.

For the estimates of the population densities through time, we have used the demographic data of Colombia available in thirteen of the seventeen national censuses that have been conducted since independence from Spain, as well as the most complete record for the indigenous population made in the early $16^{\text {th }}$ century.

\section{THE REVERSAL OF FORTUNE THESIS AND SOME OF ITS CRITICS}

The world economy has changed enormously since 1500. Many changes were produced by the European expansion overseas and the colonisation of vast territories in the Americas, Africa and Asia. According to Acemoglu et al. (2002), this expansion led to a reversal in the relative prosperity of the new territories (Acemoglu et al. 2002, p. 1231). "Among countries colonised by European powers during the past 500 years, those that were relatively rich in 1500 are now relatively poor».

The explanation for the reversal of fortune that Acemoglu et al. (2002) offer is what they call the «institutions hypothesis». According to this hypothesis, those societies that offer better opportunities for investment and protect property rights will prosper more than those that do not. The reason why institutions explain the reversal of fortune is that the impact of European expansion varied according to how densely populated the territories that were colonised after 1500 were. Those places with high concentrations of population at the time of colonisation witnessed the introduction of highly extractive institutions, such as the encomienda in Spanish America. Thus the long-run growth prospects of such places were low. In contrast, the areas that were sparsely populated attracted large numbers of European settlers. These immigrants set up institutions that permitted equality of opportunity, secure property rights and broadly based political power structures. Over the long run these territories became very prosperous. 
Acemoglu et al. (2002) illustrate their reversal of fortune thesis with the examples of Mexico and Peru, compared with the United States. While at the time of the Spanish conquest, the Incas and the Aztecs had very rich civilisations, what is now the United States was sparsely populated by indigenous people who did not have a level of prosperity comparable to the former. Today the situation is the opposite of what it had been circa 1500 .

One of the main empirical difficulties in this debate is how to measure the level of prosperity in 1500. The two measures used by Acemoglu et al. (2002) are the level of urbanisation and the degree of population density with respect to the amount of available arable land. Both measures have problems of a conceptual nature as well as with the quality of the information available. The authors present graphs on the negative correlation of the per capita GDP for 1995 with urbanisation and population densities circa 1500 for a large sample of countries. In both cases, the correlation coefficient is negative and significant (Acemoglu et al. 2002, pp. 1233-1234).

The main conclusion that Acemoglu et al. (2002) derive from the reversal of fortune result is that what they define as the simple version «geographic hypothesis» is invalidated, since they argue that it predicts persistence of fortune. These authors define the geographic hypothesis as one that: «explains most of the differences in economic prosperity by geographic, climatic, or ecological differences across countries» (Acemoglu et al. 2002, p. 1232).

Acemoglu et al. (2002) also discuss what they call the sophisticated "geographic hypothesis», with which they agree, and according to which the effect of geography will vary throughout time (Acemoglu et al. 2002, p. 1257). An example of this is the drift of economic activity that has been observed through time from the equator to the north and south. Many years ago the tropics prospered because the technology of early civilisations was well adapted to that climate. A second consideration, in the same direction, is that certain geographic conditions became more important in the process of industrialisation.

Several authors have been critical of the reversal of fortune thesis presented by Acemoglu et al. (2002). The basis for most of these negative evaluations is the weak empirical basis of their analysis. One of the first authors to question the general validity of the results of Acemoglu et al. (2002) was Adam Przeworski (2004). This author argued, using the data on income published by Angus Maddison in 2003, that the only major cases of reversal of fortune that continued to hold were those of the four British offshoots: Australia, Canada, New Zealand and the United States. Przeworski also questions the validity of the statistical methods used by Acemoglu, Johnson, and Robinson (AJR) and makes a call: «Instead of taking shortcuts, we need to study the variations among countries along their entire modern history. This means we need better data on the history of institutions» (Przeworski 2004, p. 20).

According to Gareth Austin (2008), the first problem with the thesis of the reversal of fortune as presented by Acemoglu et al. (2002) is the poor quality 
of the evidence they present. For example, the quantitative data for Africa circa 1500 is quite deficient, and this region comprises a large part of the sample used by the authors (twenty-three out of sixty-four cases; Austin 2008, p. 998). For instance, most of the population densities for around 1500 were obtained from backward projections starting with already deficient estimates for 1900. Finally, Austin (2008) questions the validity of the compressing of history by comparing two moments separated by 500 years, when in between there had been so many changes in the actors and conditions.

Sanghamitra Bandyopadhyay and Green (2011) question the results of Acemoglu et al. (2002) regarding the proxies they used for pre-modern income. For example, they argue that the measure of urbanisation used by Acemoglu et al. (2002) contains no data for Africa. When Bandyopadhyay and Green (2011) use an alternative measure of urbanisation that increases the sample from fourty-one to seventy-one observations the reversal of fortune disappears and even changes in sign. Bandyopadhyay and Green (2011) also question the handling of the information about arable land by Acemoglu et al. (2002). According to these authors, Acemoglu et al. (2002) did not have information on this variable for eighty-six of the ninety-one observations they used, so they assumed that all the land was arable. When new estimations are made with better data, the results change. Finally, these authors argue that the results of Acemoglu et al. (2002) do not hold for Africa and that they are largely influenced by the neo-Europes. When the latter are excluded, the relationship becomes weakly significant or not significant.

All of the above authors discuss the reversal of fortune hypothesis between countries. In contrast, the paper by Maloney and Valencia Caicedo (2012) uses sub-national historical data to show the within-country persistence of prosperity in the Americas since 1500. Contrary to the reversal of fortune thesis defended by Acemoglu et al. (2002), Maloney and Valencia Caicedo (2012): «...show that high pre-colonial density areas tend to be dense today; population agglomerations persists» (Maloney and Valencia Caicedo 2012, p. 1).

In their analysis Maloney and Valencia Caicedo (2012) used data for eighteen countries in the Americas. The variable they use to measure prosperity in 1500 is population density. For prosperity in 2005, they used both per capita income and population density. For example, using population density for both 1500 and 2005 they find a positive and significant relationship for fifteen out of eighteen countries. In the case of Panama and Uruguay, the relationship was not significant and only for Canada was it negative and significant. Thus, for the Americas, at the sub-national level they observe no reversal of fortune.

The current paper also studies the reversal of fortune hypothesis at the sub-national level for the case of Colombia. However, in this case the evolution of relative prosperity through time is observed using population data at various points in the $19^{\text {th }}$ and $20^{\text {th }}$ century and not just at the initial and end points. 


\section{THE DATA}

The information for the population of the Colombian departments and municipalities, the main territorial units in which the country is currently divided, comes from the national population censuses. At present, Colombia has thirty-two departments and 1,123 municipalities plus the capital city. In Figure 1, the present political division of the country into departments and municipalities is shown.

Throughout the republican history of Colombia there have been a total of seventeen national population censuses. The 1928 census is not considered in this paper because it was never approved by Congress due to a significant level of over-reporting (Flórez 2000, p. 141). Additionally, for the censuses corresponding to 1825 and 1864 the data is not sufficiently disaggregated so that it cannot be rearranged and consolidated according to the current limits of the departments. Thus, we are left with four censuses covering the $19^{\text {th }}$ century, nine for the $20^{\text {th }}$ century, and one for the present century.

The only population information used in this paper that did not come from the national censuses corresponds to an extensive record of the number Indians who had to pay tributes to the Spaniards, which existed in 1559 in the territory of what is now Colombia. Immediately after obtaining control of a territory, the Spaniards would assign specific groups of Indians among the different conquerors so they would pay a tribute in work, money or in kind. The men in working age, generally 16-60 years old, were responsible for that tribute. This institution was known as the encomienda.

For the first part of the $16^{\text {th }}$ century, historians calculate a ratio of one to three between the number of tributaries and the total population (Meisel 1980, p. 236). In 1559, there were a total of 1,119 encomiendas and 65,113 tributary Indians in what is now Colombia (Tovar 1988). Thus, the total population that can be inferred from that record, around 200,000, is below even the relatively conservative estimates for total population at the beginning of the conquest. For example, the historian German Colmenares calculated that circa 1537 the indigenous population was around 3,000,000 (Melo 1977, p. 110). Several things might serve to explain why the total population subject to encomienda in 1559 was much smaller than the probable population in $1500^{1}$. One reason is the high mortality that occurred when the indigenous population was exposed to the epidemics that the Spaniards brought to America, and which caused what has been labelled as a demographic catastrophe ${ }^{2}$. A second reason is that not all of the population

\footnotetext{
1 The conquest of the territory of what is now Colombia began in 1525. However, several years passed before the Spaniards had control of most of the territory.

2 It has been argued that the indigenous population that was most decimated by the conquest, in relative terms, was the one that had lower levels of socioeconomic development. This was precisely the natives living in the less densely populated areas. Thus, the effect of differential mortality would have been to increase differences in relative densities, not to reverse the pre-1500 levels.
} 
FIGURE 1

CURRENT LIMITS OF COLOMBIAN DEPARTMENTS AND MUNICIPALITIES

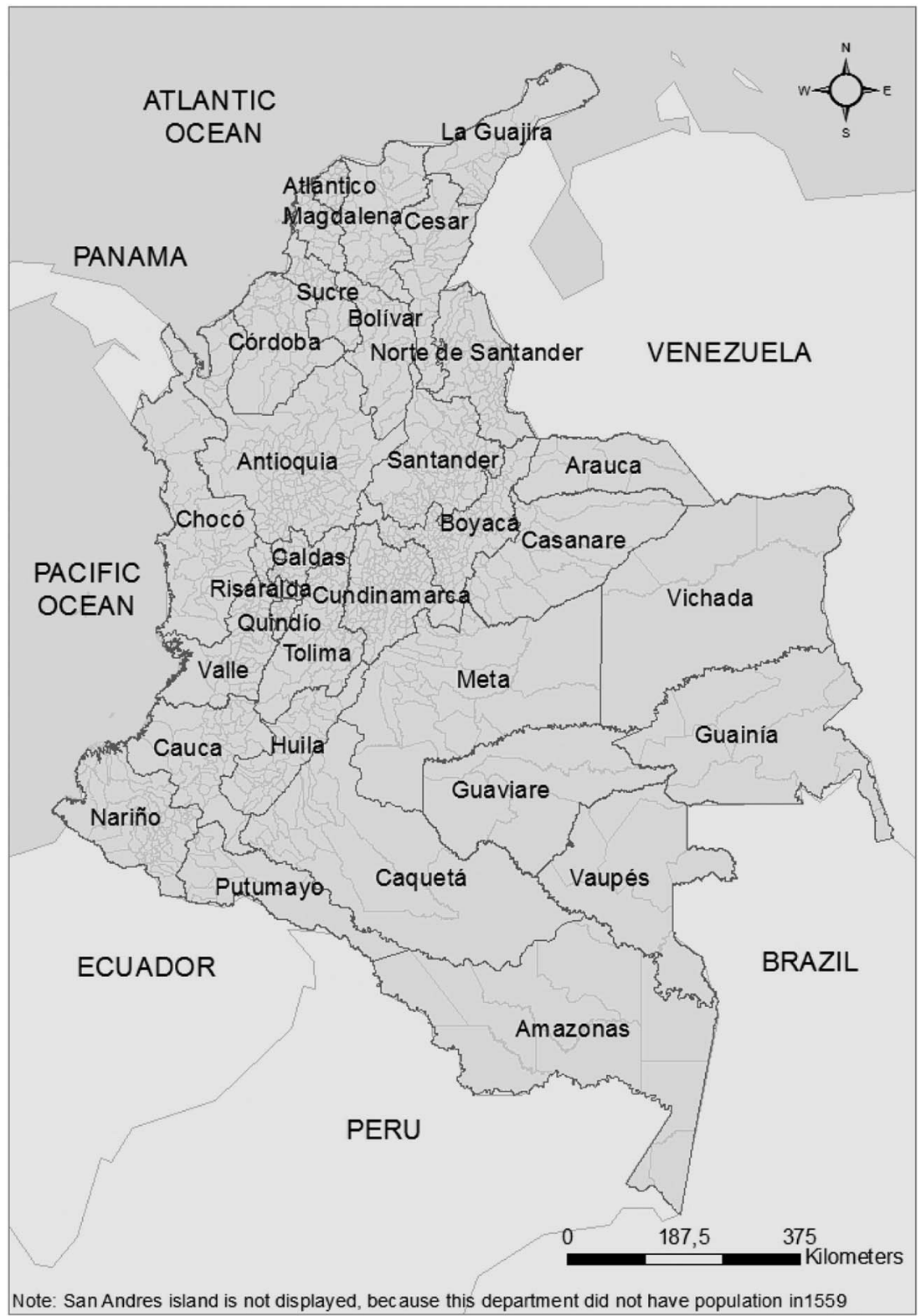

Source: Instituto Geográfico Agustín Codazzi (IGAC). 
was under the control of the Spaniards in 1559, thus they were not subject to the encomienda. However, we believe that the 1559 record of the tributaries provides a good picture of the regional population distribution in 1500, because it is highly unlikely that the mortality observed in the years since the conquest started could have changed the relative regional population densities significantly (Livi-Bacci, 2006; see footnote 2).

\section{THE SPATIAL PERSISTENCE OF PROSPERITY IN THE COLOMBIAN REGIONS, 1500-2005}

The territory of continental Colombia has an extension of 1,141,748 sq km. It is characterised by very distinct climatic, economic and cultural regions. To a great extent, this has been the result of the very rugged topography that covers much of its territory. The Andes split into three ranges that divide the country from south to north. Although the whole country is located in the tropics, the different elevations produce large variations in temperature. These variations, plus a wide variety of rainfall regimes and soils, lead to very distinct ecological conditions across the country.

The first systematic records of the location of population in what is now Colombia come from the records of the indigenous population assembled by the Spanish officials during the years of conquest. What these records reveal is that most of the population was concentrated in the mountains, at elevations between 1,000 and $3,000 \mathrm{~m}$ above sea level, where soil productivity and health conditions were better than in the tropical lowlands, which were sparsely inhabited.

Perhaps the most accurate measure of the standard of living in the Colombian regions is the recently estimated Multidimensional Poverty Index (MPI), which was constructed by the National Department of Planning using information from the 2005 population census ${ }^{3}$. The correlation coefficient between the MPI and the population density of 1559, using the geographical limits of the current departments, is -0.55 . That is, the regions that were prosperous in 1559 tend to be the same ones in 2005: thus, there is no reversal of fortune (see Figure 2). This correlation persists if we use, for both 1559 and 2005, the population density of the departments (see Figure 3$)^{4}$. In this case the correlation coefficient is 0.45 .

3 The GDP per capita of the departments is not used as a measure of regional prosperity because in many cases it is distorted by the presence of mining and oil production in some departments, which leads to very high levels of GDP, which have almost no relation with local incomes.

4 The department of Antioquia, one of the most populated at present, was excluded from the estimation for 1559 (but not for the later dates) because the number of tributary Indians reported for its territory in that year was only 298, a clear case of under-reporting, according to the evidence provided by the historical records. According to the historian Jorge Orlando Melothroughout 1557-1560 there was a generalised rebellion of the indigenous population of what is now Antioquia. 
FIGURE 2

CORRELATION BETWEEN THE POPULATION DENSITY OF COLOMBIAN

DEPARTMENTS IN 1559 AND THE MULTIDIMENSIONAL POVERTY INDEX

IN 2005

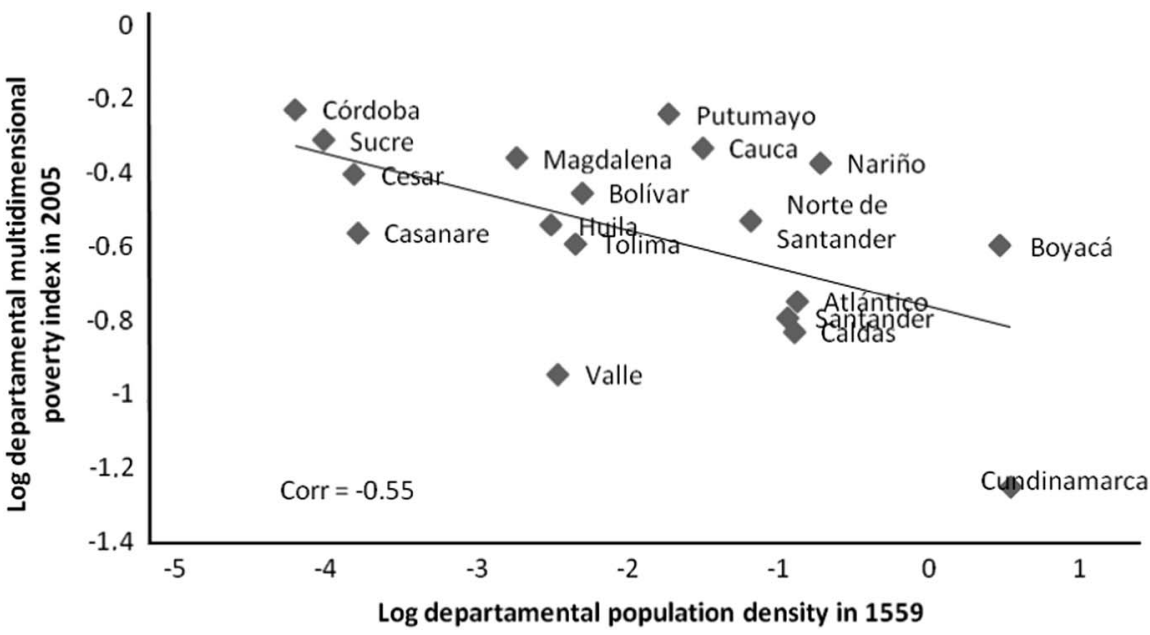

Source: Calculations based on Tovar (1988) and Departamento Administrativo Nacional de Estadistica (DANE).

Note: The department of Antioquia was removed from the sample, since its population in 1559 was underestimated (see footnote 4).

In Table 1, we present the correlation coefficient between the density of the territories that correspond to the current limits of Colombian departments and the MPI for 2005, starting in 1559. It can be observed through time that the coefficient increases as the time lag falls to zero. What is important here is that the results of persistence are rather robust and do not depend on two single observations.

In Table 2, we can observe the complete set of pairwise correlations for all the population censuses that we have used and for the 1559 enumeration of indigenous males of working age subject to the encomienda regime. All of the coefficients are significant at the 1 per cent level, except for those corresponding to 1559 with the different censuses, which are significant at the 5 and 10 per cent level. Beginning in 1835 all the correlation coefficients are above 0.73 , showing the strength of the persistence of relative prosperity

(footnote continued)

This could have been the reason for the clear underestimation of the number of tributary Indians in that region (Melo). 
FIGURE 3

CORRELATION BETWEEN THE POPULATION DENSITY OF COLOMBIAN DEPARTMENTS IN 1559 AND THE POPULATION DENSITY OF COLOMBIAN DEPARTMENTS IN 2005

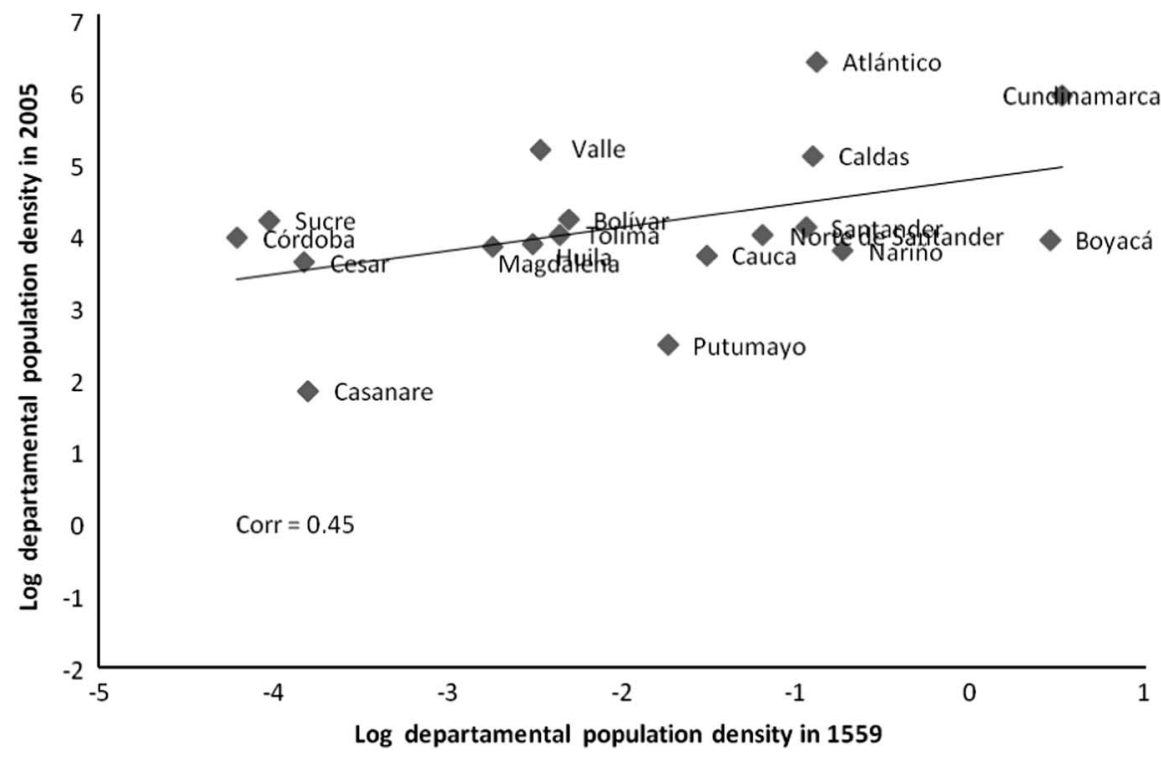

Note: The department of Antioquia was removed from the sample, since its population in 1559 was underestimated (see text).

Source: Calculations based on Tovar (1988) and DANE.

in the same locations. But even for 1559, the correlation coefficients are quite high, always above 0.45 .

In Figure 4, we can observe the population density in 1559. The density is presented in relation to the limits of the current departments. The highest density corresponds to the departments of Boyacá and Cundinamarca, which in 1500 were the areas where the Chibcha chiefdoms were located. Overall, most of the population was located in the mountainous center of the country. The rest of the country had a lower population density. A somewhat similar pattern is observed nowadays (see Figure 5). In Figure 5, we can observe that in 2005 Cundinamarca still has the highest population density, and that most of the population is located in the mountainous center of the country, with the Amazonian and Orinoquian regions, in the southeast, having the lowest density and very low altitude.

The importance of the geographic factor for the location of the Colombian population persists until the present. In Table 3, we show the results for an 
TABLE 1

CORRELATION COEFFICIENTS OF THE LOG DEPARTMENTAL POPULATION DENSITY IN DIFFERENT YEARS WITH THE MULTIDIMENSIONAL POVERTY INDEX IN 2005

\begin{tabular}{|l|c|c|}
\hline Year & Correlation coefficient & Number of observations \\
\hline 1560 & $-0.5553 * * 1$ & 18 \\
1835 & $-0.5694 * * * 2$ & 22 \\
1843 & $-0.5796 * * *$ & 22 \\
1851 & $-0.5126 * *$ & 23 \\
1870 & $-0.5796 * * *$ & 23 \\
19053 & $-0.3930 * 3$ & 22 \\
1912 & $-0.5159 * * *$ & 25 \\
1918 & $-0.5838 * * *$ & 27 \\
1938 & $-0.6163 * * * *$ & 28 \\
1951 & $-0.6264 * * *$ & 28 \\
1964 & $-0.6435 * * *$ & 28 \\
1973 & $-0.6544 * * * *$ & 29 \\
1985 & $-0.6711 * * *$ & 29 \\
1993 & $-0.6714 * * * *$ & 29 \\
2005 & $-0.6791 * * *$ & 29 \\
\hline
\end{tabular}

Note: *Significant at 10\%, **significant at 5\%, ***significant at $1 \%$.

Source: Calculations based on Tovar (1988) and DANE.

${ }^{1}$ The department of Antioquia was removed from the sample, since its population in 1559 was underestimated (see text).

${ }^{2}$ The department of Meta was removed for the years 1835, 1843, 1851 and 1870, because it behaves differently to the rest of the sample (outlier).

${ }^{3}$ For the departments of Atlántico, Bolívar, Cesar, Córdoba, Sucre and Magdalena, population and density were calculated as a proportion of the share of each department in the 1912 census.

ordinary least squares regression in which the level of poverty of the Colombian municipalities, measured by the MPI in 2005, is determined by altitude, altitude squared, per cent of ethnic population (indigenous plus Afrocolombians) and the population. Thus, we include geographical variables (altitude), institutions (per cent ethnic) and economies of scale and agglomeration (population size) ${ }^{5}$.

5 In a paper with Laura Cepeda, we show that in Colombia the current percentage of ethnic population in the departments is a good proxy for institutions of colonial origin, see Cepeda and Meisel (2013). The geographic variable is measured altitude because altitude has a direct relation with temperature, and thus with soil moisture and productivity. Since departments are heterogenous in quality of soil, rain, ruggedness and other geographic variables, it is not easy to include them in one single measure. 
TABLE 2

CORRELATION MATRIX OF POPULATION DENSITY IN DIFFERENT YEARS (1559-2005)

\begin{tabular}{|c|c|c|c|c|c|c|c|c|c|c|c|c|c|c|}
\hline $1559^{1}$ & 1835 & 1843 & 1851 & 1870 & $1905^{2}$ & 1912 & 1918 & 1938 & 1951 & 1964 & 1973 & 1985 & 1993 & 2005 \\
\hline \multicolumn{15}{|l|}{1} \\
\hline 18 & & & & & & & & & & & & & & \\
\hline $0.5776 * *$ & 1 & & & & & & & & & & & & & \\
\hline 18 & 23 & & & & & & & & & & & & & \\
\hline $8.5651^{* *}$ & 0.996 & 1 & & & & & & & & & & & & \\
\hline 18 & 23 & 23 & & & & & & & & & & & & \\
\hline $0.5816^{* * *}$ & 0.99 & 0.993 & 1 & & & & & & & & & & & \\
\hline 18 & 23 & 23 & 24 & & & & & & & & & & & \\
\hline $0.5904^{* * * *}$ & 0.969 & 0.965 & 0.987 & 1 & & & & & & & & & & \\
\hline 18 & 22 & 22 & 23 & 23 & & & & & & & & & & \\
\hline $0.5470^{* *}$ & 0.914 & 0.903 & 0.933 & 0.969 & 1 & & & & & & & & & \\
\hline 18 & 22 & 22 & 22 & 21 & 22 & & & & & & & & & \\
\hline $0.6677^{* * *}$ & 0.878 & 0.869 & 0.913 & 0.962 & 0.982 & 1 & & & & & & & & \\
\hline 18 & 23 & 23 & 24 & 23 & 22 & 25 & & & & & & & & \\
\hline $0.679^{* * * k}$ & 0.882 & 0.873 & 0.883 & 0.942 & 0.977 & 0.989 & 1 & & & & & & & \\
\hline 18 & 23 & 23 & 24 & 23 & 22 & 25 & 27 & & & & & & & \\
\hline $0.5403^{* *}$ & 0.853 & 0.845 & 0.904 & 0.951 & 0.97 & 0.979 & 0.956 & 1 & & & & & & \\
\hline 18 & 23 & 23 & 24 & 23 & 22 & 24 & 26 & 28 & & & & & & \\
\hline $0.5222^{* *}$ & 0.842 & 0.831 & 0.882 & 0.936 & 0.961 & 0.976 & 0.963 & 0.998 & 1 & & & & & \\
\hline 18 & 23 & 23 & 24 & 23 & 22 & 24 & 26 & 28 & 28 & & & & & \\
\hline $0.4952^{* * *}$ & 0.814 & 0.801 & 0.851 & 0.91 & 0.935 & 0.959 & 0.96 & 0.99 & 0.995 & 1 & & & & \\
\hline 18 & 23 & 23 & 24 & 23 & 22 & 24 & 26 & 28 & 28 & 28 & & & & \\
\hline $0.4631^{*}$ & 0.804 & 0.787 & 0.851 & 0.89 & 0.92 & 0.953 & 0.964 & 0.976 & 0.982 & 0.994 & 1 & & & \\
\hline 18 & 23 & 23 & 24 & 23 & 22 & 25 & 27 & 28 & 28 & 28 & 29 & & & \\
\hline $0.4634 *$ & 0.777 & 0.756 & 0.813 & 0.864 & 0.895 & 0.942 & 0.952 & 0.971 & 0.978 & 0.993 & 0.997 & 1 & & \\
\hline 18 & 23 & 23 & 24 & 23 & 22 & 25 & 27 & 28 & 28 & 28 & 29 & 29 & & \\
\hline $0.4695^{* *}$ & 0.767 & 0.745 & 0.803 & 0.853 & 0.887 & 0.936 & 0.961 & 0.971 & 0.98 & 0.99 & 0.993 & 0.995 & 1 & \\
\hline 18 & 23 & 23 & 24 & 23 & 22 & 25 & 27 & 28 & 28 & 28 & 29 & 29 & 29 & \\
\hline $0.4522^{*}$ & 0.758 & 0.738 & 0.798 & 0.841 & 0.867 & 0.924 & 0.951 & 0.965 & 0.973 & 0.985 & 0.991 & 0.994 & 0.999 & 1 \\
\hline 18 & 23 & 23 & 24 & 23 & 22 & 25 & 27 & 28 & 28 & 28 & 29 & 29 & 29 & 29 \\
\hline
\end{tabular}

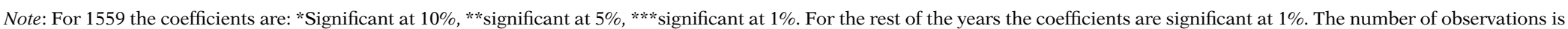
below each coefficient.

Source: Calculations based on Tovar (1988) and DANE.

${ }^{1}$ The department of Antioquia was removed from the sample in the correlations for 1559, since its population in that year was underestimated (see text).

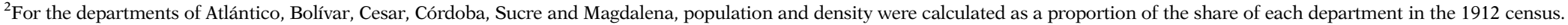


FIGURE 4

STANDARDISED POPULATION DENSITY IN 1559 USING CURRENT DEPARTMENTAL LIMITS

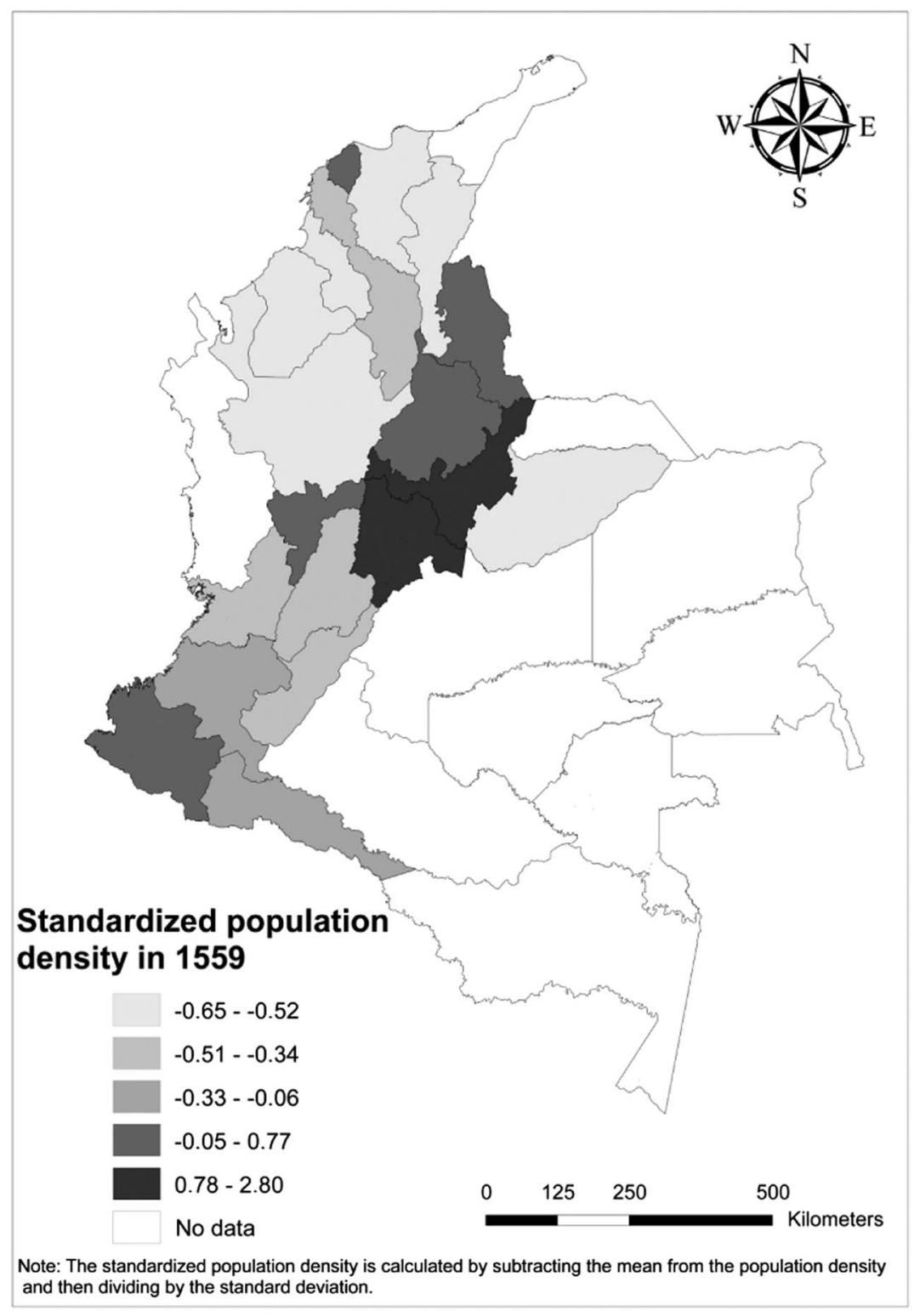

Source: Calculations based on Tovar (1988). 
FIGURE 5

STANDARDISED POPULATION DENSITY IN 2005

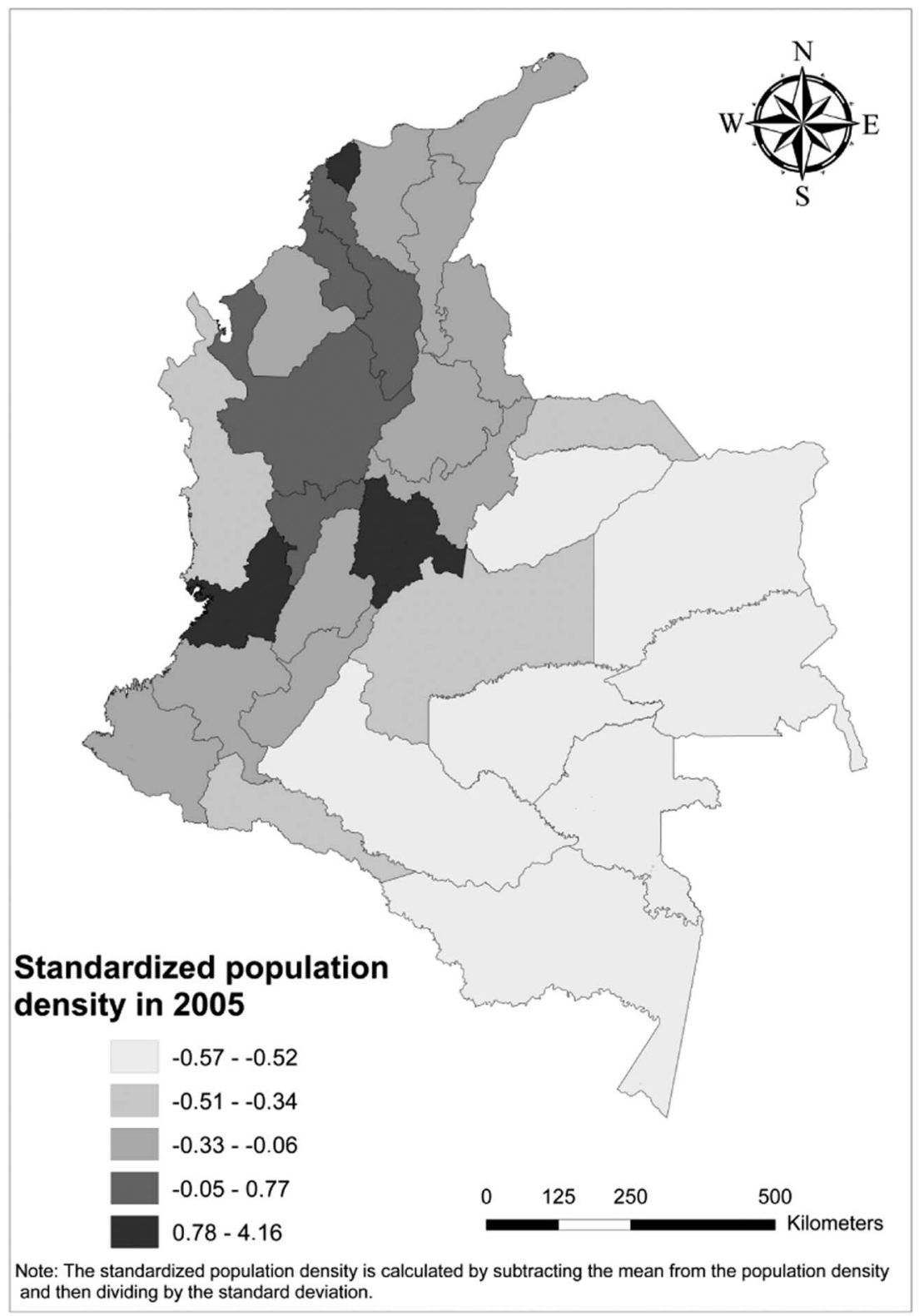

Source: Calculations based on DANE. 
TABLE 3

DETERMINANTS OF THE MUNICIPAL POVERTY INDEX IN COLOMBIA IN 2005

\begin{tabular}{|l|c|c|c|}
\hline & Coefficients & Standard robust error & $P$-value \\
\hline Altitude & -0.00010 & 0.000 & 0.000 \\
Altitude $^{2}$ & $2,72 \mathrm{E}-08$ & 0.000 & 0.000 \\
\%Ethnic population & 0.0015206 & 0.000 & 0.000 \\
Quartile population 2 & -0.02305 & 0.009 & 0.011 \\
Quartile population 3 & -0.0504599 & 0.010 & 0.000 \\
Quartile population 4 & -0.1828065 & 0.012 & 0.000 \\
Constant & 0.7919448 & 0.010 & 0.000 \\
\hline No. observations 1,047 & $R^{2}=0.37$ & \multicolumn{2}{|c|}{$P$-value (Test F) 0.000} \\
\hline
\end{tabular}

Note: The quartiles of population are binary variables, taking the value of one if the municipality belongs to a given quartile. The comparison group is the municipalities of the first quartile, that is the least populated of them.

Source: DANE and estimations by the author.

In Figure 6 and Figure 7, we illustrate more clearly the strong association between the location of the Colombian population and the Andes mountains, and therefore with altitude. For 1835, Figure 6 shows that the immense majority of the municipalities were located in the three ranges (Occidental, Central and Oriental) in which the Andes split in Colombia. In that year, there was a second cluster of municipalities, located on the Caribbean Coast, around the seaports of Barranquilla, Cartagena and the lower Magdalena River. The pattern of location of the municipalities observed for 2005, Figure 7, is not very different from what had been observed in 1835, with the exception that many more municipalities had been created, by dividing those already existing. Additionally, the southeastern regions had become more populated, although the density continues to be relatively low.

\section{CONCLUSIONS}

One of the main empirical arguments that AJR present in favour of the primacy of institutions over geography in the discussion about the long-run determinants of prosperity is the reversal of fortune thesis. Their empirical evidence is based on comparisons between countries. This reversal of fortune may not hold for the sub-national level as has been shown by Maloney and Valencia Caicedo (2012) for the Americas. Perhaps the existence of similar «national» institutions within a country makes it more likely that relative prosperity may persist over time in the same locations. This would indicate that geographic differences are more important in explaining economic differences within a country than between countries. 
FIGURE 6

COLOMBIAN PHYSICAL GEOGRAPHY AND THE LOCALISATION OF THE MUNICIPALITIES IN 1835

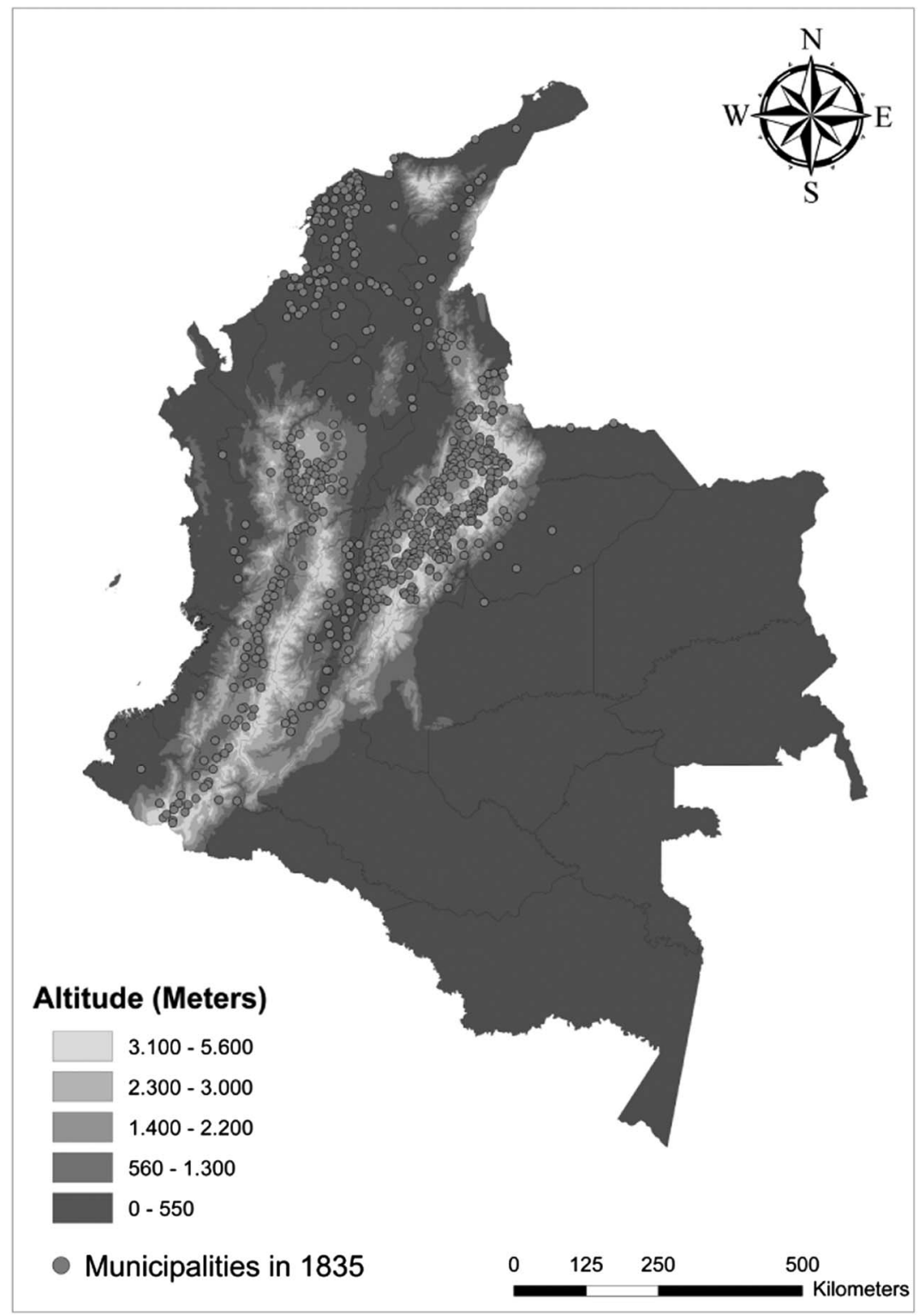

Source: Instituto Geográfico Agustín Codazzi (IGAC). 
FIGURE 7

COLOMBIAN PHYSICAL GEOGRAPHY AND THE LOCALISATION OF THE MUNICIPALITIES IN 2005

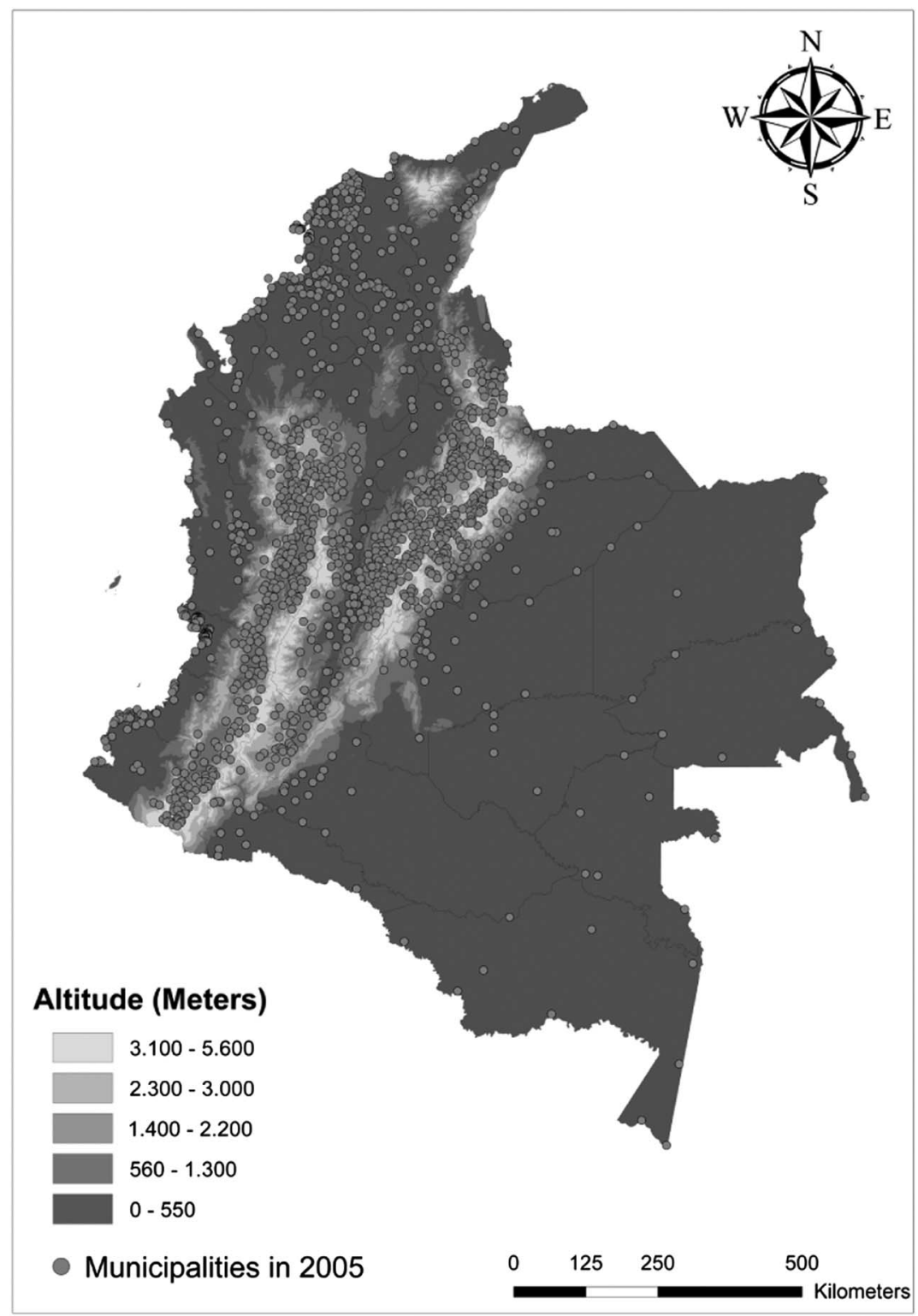

Source: Instituto Geográfico Agustín Codazzi (IGAC). 
In this paper, we have shown that for Colombia in the period 1559-2005 there is no evidence of a reversal of fortune. Rather, what is observed is a robust persistence of the pre-hispanic patterns of wealth. We have also shown that location is closely related to altitude, which affected the weather and the humidity of the soil, and therefore positively influenced the productivity of agriculture as well as the prevailing health conditions.

One of the main advantages of the empirical evidence we present in this study is that we use a total of fourteen censuses, from 1835 to 2005. Thus, what occurred through time is taken into account and not just the initial and end points of the period analysed. The main message from this result relates to the spatial persistence of relative prosperity in Colombia over the last 500 years and the non-negligible influence of geography in the regional distribution of that prosperity.

\section{REFERENCES}

Acemoglu, D.; Johnson, S., and Robinson, J. (2002): «Reversal of Fortune: Geography and Institutions in the Making of the Modern World Income Distribution». Quarterly Journal of Economics 117 (4), pp. 1231-1294.

Austin, G. (2008): «The «Reversal of Fortune» Thesis and the Compression of History: Perspectives from African and Comparative Economic History». Journal of International Development 20 (8), pp. 996-1027.

Bandyopadhyay, S., and Green, E. (2011): "The Reversal of Fortune Thesis Reconsidered». Journal of Development Studies, 48 (7), pp. 817-831.

Cepeda, L., and Meisel, A. (2013): «¿Habrá una segunda oportunidad sobre la tierra? Instituciones coloniales y disparidades económicas regionales en Colombia», Documentos de trabajo sobre economía regional, CEER, Banco de la Republica, Cartagena, No. 183.

FlóREZ, C. (2000): Las transformaciones sociodemográficas en Colombia durante el siglo $X X$. Bogotá: Banco de la República-TM Editores.

Livi-Bacci, M. (2006): «The Depopulation of Hispanic America after the Conquest». Population and Development Review 32 (2), pp. 199-232.

Maloney, W., and Valencia Caicedo, F. (2012): «The Persistence of (Subnational) Fortune: Geography, Agglomeration, and Institutions in the New World», Documento $C E D E$, No. 2, Bogotá.

Meisel, Roca A. (1980): «Esclavitud, mestizaje y haciendas en la Provincia de Cartagena, 1533-1851», Desarrollo y sociedad, No. 4, CEDE, Universidad de los Andes, Bogotá.

Melo, J. (1987): «La conquista de Antioquia, 1500-1800». Available at htpp//jorgeorlandomelo.com.

Melo, J. (1977): Historia de Colombia, El Establecimiento de la dominación española, Tomo I. Medellín: Editorial La Carreta.

Przeworski, A. (2004): Geography vs. Institutions Revisited: Were Fortunes Reversed? Department of Politics: New York University, New York.

Tovar, H. (1988): No hay caciques ni señores, Relaciones y visitas a los naturales de América, Siglo XVI. Barcelona: Sendai Ediciones. 